\title{
Innovation Strategies within the Transforming Russian Electric Power Sector
}

\author{
Yegor D. Burda* \\ National Research University Higher School of Economics \\ Moscow, Russian Federation
}

Received 25.05.2021, received in revised form 15.06.2021, accepted 29.06.2021

\begin{abstract}
Currently, Russian electric power sector is influenced by two divergent tendencies: on the one hand, we can observe a structural transformation of the industry and increasing role of innovations; on the other hand, it is still subject to regulation, while reliability and safety of power supply remain of paramount importance. This situation creates a unique opportunity to explore which innovation strategies are chosen by companies and which factors have the greatest influence on their decisions. A qualitative study was conducted based on a set of semi-structured interviews with several managers of Russian power companies. Further analysis allowed to reveal the dominant innovation strategies employed within the industry: traditional contracts, in-house development, closed and open innovation ecosystems. This study also revealed factors that determine the choice of an innovation strategy: goals of the firm and type of market it aims to operate at. The results provide managers with insights allowing them to make better-grounded decisions in terms of choosing an innovation strategy within various settings.
\end{abstract}

Keywords: innovations, innovation strategy, innovation ecosystem, interfirm collaboration, electric power sector.

The reported study was funded by RFBR, project number 19-310-90065.

Research area: economics.

Citation: Burda, Y.D. (2021) Innovation strategies within the transforming russian electric power sector. J. Sib. Fed. Univ. Humanit. Soc. Sci., 14(7), 1092-1102. DOI: 10.17516/1997-1370-0787.

(C) Siberian Federal University. All rights reserved

* Corresponding author E-mail address: yburda@hse.ru 


\title{
Стратегии создания инноваций в трансформирующейся электроэнергетике России
}

\author{
Е.Д. Бурда \\ Национальный исследовательский университет \\ «Высшая школа экономики» \\ Российская Федераичи, Москва
}

\begin{abstract}
Аннотация. В настоящее время российская электроэнергетика находится под влиянием двух разнонаправленных тенденций: с одной стороны, происходит структурная трансформация отрасли и повышается роль инноваций; а с другой - в ней по-прежнему сохраняется высокая степень государственного участия и первостепенность вопросов надежности и безопасности энергоснабжения. Это создает уникальную возможность для изучения того, какие стратегии создания инноваций выбирают компании в текущих условиях и какие факторы оказывают наибольшее влияние на этот выбор. Путем проведения качественного исследования, основанного на ряде глубинных полуструктурированных интервью с руководством компаний отрасли, были выявлены доминирующие стратегии создания инноваций: традиционные контракты, собственные разработки, закрытые и открытые инновационные экосистемы. Исследование также позволило выявить факторы, определяющие выбор стратегии: преследуемые фирмой цели и тип рынка, на котором она планирует функционировать. Полученные результаты позволят менеджерам принимать более взвешенные решения в части выбора стратегии создания инноваций в различных условиях.
\end{abstract}

Ключевые слова: инновации, инновационная стратегия, инновационная экосистема, взаимодействие фирм, электроэнергетика.

Научная специальность: 08.00.00 - экономические науки.

\section{Introduction}

Ongoing energy transition, wide spread of various innovative technologies and disintegration of industrial value chain requires the development of new collaboration practices among companies of Russian electric power sector (Zubakin, 2019; Markova, Churashev, 2020). On the one hand, digital transformation and technological advancements attract new players to the industry aimed to satisfy expanding consumer requirements by developing various innovative products and services. On the other hand, consumers become more active and are no longer satisfied with the traditional supply of electricity and power - they want to manage their consumption and ultimately decrease the overall spending on electricity.

These transformations increase the interdependence among industry players and create a fruitful basis for the development of various innovation ecosystems (IEs) - specific form of collaboration based not on formal market mechanisms or hierarchy but on a process of cocreation of innovative value propositions, which would benefit the customer (Adner, 2006, 2017; Jacobides et al., 2018). However, development of IEs is very challenging for electric power companies. First, increasing role of innovative value propositions (Khovalova, 2019) forces electric power companies to collaborate with others both inside and outside the boundaries of the industry and correspondingly adopt their innovation strategies. Second, spread of new technologies and the overall increase in speed of technological changes requires greater flexibility and adaptability. Third, we can observe a decreasing role of products - there is a transition towards a service-dominant logic (Kleiner et al., 2020), focused on the process of providing services and collaboration with consumers. These 
transformations force companies to reconsider their innovation strategies with a greater focus on collaboration.

At the same time, electric power sector still preserves a set of its essential features: a high degree of government regulation, dominance of big state-owned companies (Aizenberg, Dzuba, 2020) and paramount role of reliability and safety (Energy Strategy of Russia, 2020). Moreover, specific nature of electricity as a product requires for compatibility of products and services provided by different companies.

Taken together, the abovementioned divergent forces within the sector create a unique opportunity to study innovation strategies of electric power companies and the IE phenomenon in particular. Two research questions are of particular interest: (1) which innovation strategies are chosen by companies under such conditions (and if firms apply to IEs, how do they do it); and (2) which factors determine the choice of a particular innovation strategy (IE in particular).

This study aims to provide managers with the conceptual decision-making framework for those cases when a transforming nature of the industry requires a reconsideration of innovation strategies and adoption of a more collaboration-centric approaches. At the same time, conducted research may provide important empirical evidence on the IE phenomenonin particular, it highlights possible peculiarities of this form of innovation strategy in different contexts and reveals factors that lead to the adoption of IE approach by the studied firms.

\section{Theoretical framework}

Considering the abovementioned shifts in the studied sector it can be argued that innovations become the major source of competitiveness. At the same time, regarding the fact that the development of innovative products and/or services within Russian electric power sector is associated with considerable financial investments, high complexity and substantial risks, which promotes the collaboration among firms, this study will adopt an inter-organizational level of analysis (Bogers et al., 2017).

Currently, there are numerous studies devoted to the investigation of various forms of innovation practices adopted by firms (Chiaroni et al., 2011; Foss et al., 2011, 2013; Foss, Foss, 2005), foundations of innovations (Demircioglu, 2016; Mazzucchelli et al., 2019; Nuruzzaman et al., 2017; Schueffel, 2015), and organizational mechanisms underlying such strategies (Cassiman, Veugelers, 2006; Demircioglu, 2016; Grigoriou, Rothaermel, 2014). At the same time, over the past decade we can observe an increasing interest towards a specific form of innovation strategy adopted by firms - IEs, which are increasingly regarded as an important way of creating and capturing value from complex value propositions (Dattee et al., 2018).

Basing on the seminal definition by Adner (2006, 2017), IEs can be described in terms of a focal firm and a set of complementary firms supporting it in terms of co-creation of innovative value propositions according to the requirements set by consumer. Complementing this definition with more recent studies on the subject (Jacobides et al., 2018), it can be argued that ecosystem represents a specific form of collaboration among economic agents based on multilateral non-universal complementarity without complete hierarchical control.

Modern research field on the subject provides multiple evidence on the conceptual nature of the phenomenon (e. g., Adner, 2006, 2017; Adner, Kapoor, 2010, 2016; Dattee et al., 2018; Jacobides et al., 2018), its emergence and development (e. g., Adner, Kapoor, 2010, 2016; Dedehayir et al., 2017; Kolloch, Dellermann, 2018; Luo, 2018), specificity of collaboration among participants (e. g., Adner, Kapoor, 2010, 2016; Davis, 2016), and distribution of results of such collective efforts (e. g., Holgersson et al., 2018; Ritala et al., 2013). However, we still lack empirical evidence on the choice of a particular innovation strategy (Tavassoli, Karlsson, 2015) and the role of IEs in this process. Therefore, this study aims to address this research gap by conducting an empirical investigation of innovation strategies and the role of IEs within the transforming Russian electric power sector.

\section{Statement of the problem}

Given the transforming nature of the Russian electric power sector, companies face an 
increasing pressure in terms of developing and delivering innovative solutions. While there is no doubt regarding the importance of such activities, the choice of innovation strategy is of particular difficulty. On the one hand, specific nature of the electric power sector sets conceptual guidelines of behavior for the companies - their solutions should be compatible and comply with the established standards. On the other hand, increasing variety of industry participants and shifting consumer demands lead to the divergence of business practices, therefore sophisticating the choice of innovation strategy.

Therefore, this study aims to reveal the existing innovation strategies adopted by firms in Russian electric power sector (with the particular emphasis on IEs), while at the same time investigating the factors that determine the choice of a particular strategy.

\section{Methods}

Overall, this study can be divided into three major stages. (1) Preliminary stage in- cluded informal interviews and discussion with industrial experts, participation in group discussions organized by various companies of the industry and devoted to innovative development. Collected data allowed to gain an indepth understanding of the industrial context and construct the main research.

(2) Main research included data collection, its analysis and development of preliminary conclusions. The nature of the research questions of the present study requires an in-depth understanding of the decision-making processes within the studied companies. Therefore, this research adopts a mixed approach based on multiple holistic case-study (Yin, 2009) of 11 companies within Russian electric power sector of different specialization, size and ownership, and representing all three major segments of the industrial value chain, namely generation, networks, sales and supplementary services (Fig. 1).

Data was collected on the basis of 12 indepth semi-structured interviews with the top management of the studied companies respon-
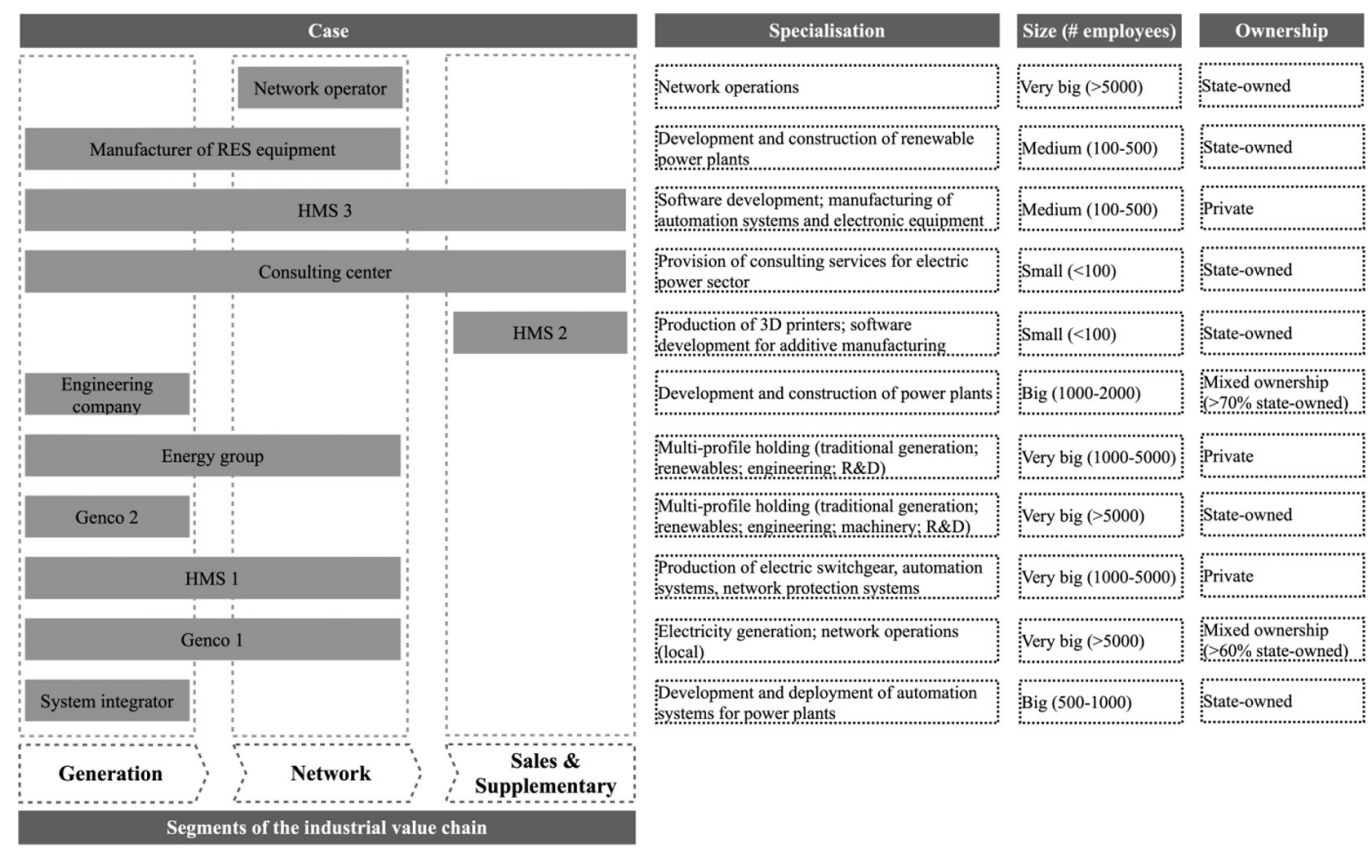

Notes: Genco - generation company; HMS - hi-tech manufacturer and software development; RES - renewable energy source; R\&D - research and development.

Source: compiled by the author.

Fig. 1. Brief description of the cases 
sible for the innovative agenda. Semi-structured format allowed to include follow-up (Spradley, 1979) and background questions therefore covering additional important topics and obtaining a balanced picture (Langley, 1999). At the same time, the following open sources were used for triangulation: mass-media, web sites and social media pages of the studied companies, industry and analyst reports.

Data analysis was performed simultaneously with the interviews in order to secure the obtained results and carefully structure them. Open coding was used in order to reveal relevant concepts, while axial coding allowed to group these concepts into categories and investigate the connection among the latter (Gioia et al., 2012).

(3) Control stage of the research was devoted to clarification of results and development of final conclusions. It included unstructured interviews with three randomly selected representatives of the studied companies. The interviews were aimed at validating the results and revealing additional important factors. These interviews also allowed to describe and present the results of this study more intelligible for the professional community and a wide readership.

\section{Discussion}

\section{Dominant innovation strategies}

Conducted analysis revealed that innovation strategies adopted by the analyzed companies can be divided into four main types: (1) contracts; (2) in-house developments; (3) closed IEs; (4) open IEs.

Contracts imply that a company has a set of long-term relations with its partners who provide necessary products and services. There are two major reasons why studied companies adopt this form of collaboration. On the one hand, the long-term nature of relations is determined by the duration of innovative projects. On the other hand, long-lasting collaboration between the company and its partners allows the latter to study the specificity and requirement of its business therefore allowing them to propose relevant products and services. This form of cooperation allows companies to achieve greater predictability and decrease transaction costs of collaboration.

In-house developments imply that a company has substantial resources and capabilities for creating innovations and therefore does not require to collaborate with external partners. Such companies do have a strong R\&D base (including specialized research institutes), which allows them to constantly produce required innovative products and services. Moreover, ownership of the resources and capabilities allows for a greater degree of predictability and control. At the same time, several respondents highlighted the fact that sometimes it is impossible to collaborate at all - high entry barriers (e. g. capital investments) discourage new players to enter certain segments of the industry.

The other two types of innovation strategies are not common for the electric power sector and incorporate a greater deal of collaboration among the company and its partners. Thus, closed IEs imply collective creation of innovations by leveraging resources and capabilities of external partners. This strategy is particularly relevant in those cases when consumers require complex systemic solutions, which are economically impractical to develop by the virtue of single efforts. A company concentrates on the development of core components (e. g., control systems for generating equipment), while external partners develop various additional modules. The nature of this strategy (closed) is determined by the fact that a company collaborates with its partners in non-essential areas of business and limits their access to the available resources (which are perceived to be a source of competitive advantage).

Creation and development of open IEs follows the same logic except that collaboration with external partners is considered as a key activity of the company and serves as a source of competitive advantage for its main business. Through tight collaboration with external partners the company gains the ability to create the required innovative products and services while at the same time increasing its flexibility in the changing environment. Moreover, having a wide set of partners allows inte- 
grating various solutions, therefore increasing competitiveness on the market. Considering this, companies adopting this strategy demonstrate greater openness in terms of access to their resources by partners $(R \& D$ facilities, expertise) - resources are not considered to be the source of competitive advantage, they are treated as a source for increasing flexibility and adaptability.

\section{Approach towards selecting \\ an innovation strategy and the role of innovation ecosystems}

The choice of a particular innovation strategy among the studied companies is determined by two major factors: (1) goal perceived by a company and (2) type of market it is aiming to operate at. The goal perceived represents an intended behavior of the company and defines its strategy - focus on the core business or aiming at market/product development. Type of the market is considered from the perspective of the company - it is either current or new for a particular company. These factors allow to construct a two-dimensional matrix demonstrating which innovation strategies do the companies under analysis adopt in various conditions (Fig. 2).

As we can see from the matrix in Fig. 2, analyzed firms tend to adopt contracts in those cases when they are focused on their core business and are not planning to enter a new market. These companies operate within stable segments of the market with relatively slow pace of changes and have an established network of long-term partners who provide them with the ready-made solutions. Such companies do not tolerate risks and are focused on incremental innovations associated with their existing products and services.

For instance, "Genco 1», being a major player on the wholesale electricity market and focusing on the issues of reliability and safety (its strategy is focused on maintenance and modernization of generating equipment), collaborates with a limited set of trusted partners, who are familiar with the company's requirements and specificity of its business and are

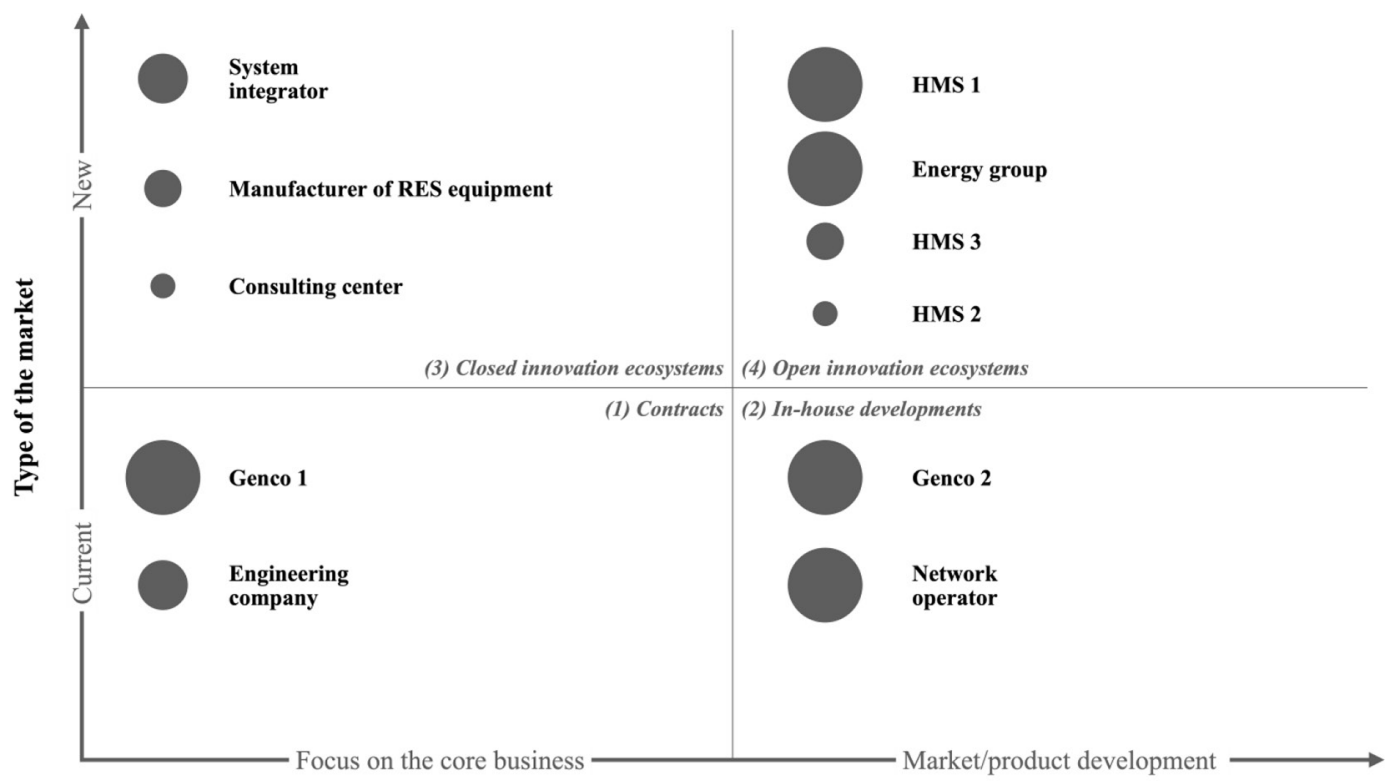

Perceived goal

Notes: size of the circle represents the size of the company; Genco - generation company; HMS - hi-tech manufacturer and software development; RES - renewable energy source.

Source: compiled by the author.

Fig. 2. Choosing an innovation strategy and the role of innovation ecosystem 
able to support suitable products and services turbines, generators, transformers, secondary switching equipment, etc. «Engineering company» demonstrates similar behavior - it acts as a main contractor and focuses on engineering and construction of buildings and generation facilities for its clients, while external partners provide necessary equipment: generating equipment, switchgear, etc.

In-house developments are widely used by those companies aimed at product/market development at their current market. Moreover, such companies, being well-established players of the industry, are self-sufficient in terms of developing innovative products and services. There are several reasons for such autonomy. First, such companies own significant R\&D facilities, which are able to fulfill their requirements in terms of innovations. Second, specific nature of their business requires very specific innovations, which cannot be applied on the market. Third, sometimes there are no external partners who can provide company with the necessary innovative solutions - either due to the abovementioned specificity of its business or due to the high entry barriers of the industry.

For instance, «Genco 2» owns a specialized R\&D institute focused on the development of new energy technologies (small-scale generators, high-temperature superconductors), research on life extension for the existing equipment and improving its efficiency (increasing its capacity factor). Its capabilities exceed those existing on the market, therefore «Genco 2 » has no reasons to apply for external partnership.

«Network operator» demonstrates similar behavior by relying on its specialized innovation business unit - regarding the specific nature of its business, there are no external partners who are able to provide company with the required digital solutions (e. g., digital substations, active network elements, monitoring systems) as well as specific network equipment and software. Even if there are external partners specializing in a particular technological domain (e. g., asset management software), their solutions require a high degree of customization for the company; thus, it is usually easier to develop the necessary solutions in-house.
Closed IEs allow companies to focus on their core business by the virtue of entering related markets with the great potential of future growth. At the same time, being new from companies' perspective they represent novel market segments with the corresponding existence of pioneering companies to compete and collaborate. Collectively created solutions are closely related to the core business of such companies and are considered supporting, are based on their valuable resources and therefore are closely governed. Being beware of potential threat to their competitiveness, they apply for collaboration in additional areas in relation to the core value proposition and therefore limit access their partners to the available pool of resources.

For instance, «System integrator» develops integrative systems (core component of the value proposition) on its own while external partners are responsible for the development of particular additional modules (sub-systems related to security, control systems for specific electric equipment), which can be combined in accordance with the consumer requirements. Partners have limited access to the available resources of the company (including the source code and other intellectual property) within a particular project and are able to use them in accordance with the established set of rules. This type of strategy allows the company to enter related markets (RES-based generation) by leveraging the established practices of modular development.

Similar strategy is adopted by «Manufacturer of RES equipment». The company decided to move beyond its core business and enter related market of commercial dispatching by the virtue of developing an ecosystem of partners providing complementary expertise and offerings (electricity storage equipment, asset management software). At the same time, the company secured its central role within the ecosystem by promoting its own specific equipment and therefore "coupling» its partners to use it within various projects.

Open IEs are adopted in those cases when company pursues the goal of entering a new market through product/market development. These markets possess great potential, are 
characterized with high pace of changes and therefore require companies to be flexible and adaptive. Necessity to compete with pioneering companies and ability to collaborate with them creates a unique opportunity for those companies ready to focus on market/product development. Within such dynamic environment such companies are able to utilize their key assets consumer base and existing resources in order to take a central role within the ecosystem and coordinate activities performed by external partners. At the same time, high pace of changes in the industry diminishes the role of formal contracts (which are too long and too difficult to develop and maintain and which may be irrelevant in case of a major technological shift) therefore forcing companies to adopt collaboration based on complementarity. Companies provide external partners with the access to their resources and co-create innovative solutions, which are able to benefit consumers. At the same time, provision of such access allows them to secure their proprietary role within the ecosystem and create high switching costs for the partners who may decide to develop competing solutions based on a different technology. Moreover, complementary resources and capabilities of external partners create synergies for companies therefore creating another incentive to support the ecosystem.

For instance, «HMS1» initially specializing in the manufacturing of vacuum switching equipment decided to enter the «smart grid» market by developing an ecosystem of partners. Simultaneously leveraging its own resources and capabilities (expertise in manufacturing and software development for electric power sector) and those provided by external partners (RES equipment, electricity storage, software for managing distributed generation and «smart grid») the company is able to provide its customers with a full scope of solutions (both in electricity generation and distribution). The company acts as a coordinator of activities performed by external partners, provides them with an access to the required resources and capabilities; therefore, allowing them to specialize in their core business.

«Energy group» adopts a similar strategy. Initially being a traditional fossil-fuel based generating company it decided to move towards «greener» and more sustainable RES-based solutions. At the same time, realizing shifts in consumer requirement, the company started to develop new businesses - both related (demand management, electricity storage) and not related (infrastructure for electric vehicles) to its core business. Lacking the required expertise but having an established consumer base, the company decided to develop its ecosystem via collective $R \& D$ with external partners. In a similar manner to «HMS1» the company acts as a coordinator of activities performed by its partners involved in the development of complementary products and services (software development - including big data based analytical and management systems, platform solutions, etc.) while maintaining its core role within the ecosystem (collaborating with the consumer at single point of contact fashion).

Innovation strategy of «HMS3» is similar to that one adopted by «HMS1» - the company moved beyond pure manufacturing and started executing various collective innovative projects on «smart grids». Having a substantial expertise in equipment manufacturing and software development, the company acts as a coordinator of such projects - it develops high-level automation systems while its partners supply complementary offerings (electricity storage, RES-based generating equipment, etc.). These solutions are collectively developed in order to secure their compatibility and achieve potential synergies in terms of utilizing heterogeneous resources and expertise.

«HMS2» represents a unique case - being a pioneering company within the newly emerged segment of additive manufacturing it had no previously established partnerships or substantial R\&D facilities. Therefore, its strategy was initially ecosystem-based. Specializing in detail optimization, 3-D printing and reverse engineering, the company is able to concentrate on these activities therefore securing its central role within the ecosystem and provide partners an access to its resources in order to develop complementary offerings (specific software, large scale manufacturing of previously engineered parts of the equipment, etc.). Open access to its resources and capabilities is 
beneficial both for the company itself and its partners - the former is able to strengthen its position within the ecosystem (partners are «locked in» on its hardware) while the latter are able to benefit in terms of access to already established technology (they obviate the necessity to make their own developments).

\section{Conclusion}

This study is devoted to the analysis of innovation strategies adopted by companies within the Russian electric power sector during its transformation. In particular, it aims to outline the major innovation strategies chosen by companies within such conditions and to uncover which factors determine the choice of a particular innovation strategy with a particular emphasis on the role of IEs. Intended contribution is to provide managers with the conceptual decision-making framework for those cases when the transforming nature of the industry requires reconsideration of innovation strategies and adoption of more collaboration-centric approaches.

The conducted research revealed four prevailing innovation strategies adopted by the studied companies, namely (1) contracts, which imply «buyer-supplier» type of relations between a company and a set of its long-term partners; (2) in-house developments, when a company has substantial resources and capabilities for creating innovations and therefore does not require to collaborate with external partners; (3) closed IEs, which implies collective creation of innovations by leveraging resources and capabilities of external partners, however limiting their access to the available resources that are considered as a source of competitive advantage; (4) open IEs, when collaboration with external partners is considered as a key activity of the company which provides it with greater access to available resources.

At the same time, the choice of a particular innovation strategy by the studied companies is determined by two major factors: (1) goal perceived by a company (focus on the core business or market/product development) and (2) type of market it is aiming to operate at (current or new for a particular company). The studied companies adopt contracts in those cases when they are focused on their core business and are not willing to enter new markets. Such companies do not tolerate risks and are focused on the incremental innovations within their existing solutions through procurement of necessary products and services from trusted providers.

In-house developments are used by wellestablished players of the industry aimed at product/market development at their current market. Such companies are self-sufficient in terms of developing innovative products and services - they have all the necessary resources and capabilities, which usually exceed those available on the market.

Closed IEs are created and developed by companies, which focus on their core business by the virtue of entering related markets with the great potential of future growth. Solutions collectively created by company and its external partners are closely related to its core business and are considered to be of supporting nature. Such products and services are based on valuable resources and therefore collaborations with partners are closely governed.

Open IEs are adopted in those cases when companies pursue the goal of entering a new market with great growth potential through product/market development. This dynamic environment provides companies with the possibility to utilize their key assets - consumer base and existing resources in order to take a central role within the ecosystem and coordinate activities performed by external partners. Companies provide external partners with an access to their resources and co-create innovative solutions, which are able to benefit the consumer. At the same time, provision of such access allows them to secure their proprietary role within the ecosystem. Moreover, complementary resources and capabilities of external partners create synergies for companies therefore creating another incentive to support the ecosystem.

Results of the present study contribute to a better understanding of the specificity of innovation strategies adopted by companies in Russian electric power sector during its transformation - IEs in particular. This study provides managers with the conceptual decision-making 
framework for those cases when the transforming nature of the industry requires reconsideration of innovation strategies and adoption of a more collaboration-centric approaches. In particular, it helps to understand which factors determine the choice of a particular innovation strategy (IE in particular) under the given conditions.

\section{References}

Adner, R. (2006). Match your innovation strategy to your innovation ecosystem, In Harvard Business Review, 84 (4), 98-107.

Adner, R. (2017). Ecosystem as structure: An actionable construct for strategy, In Journal of Management, 43 (1), 39-58.

Adner, R., Kapoor, R. (2010). Value creation in innovation ecosystems: How the structure of technological interdependence affects firm performance in new technology generations, In Strategic Management Journal, 31, 306-333.

Adner, R., Kapoor, R. (2016). Innovation ecosystems and the pace of substitution: Re-examining technology s-curves, In Strategic Management Journal, 37, 625-648.

Aizenberg, N. I., Dzuba, S. A. (2020). Proiavlenie rynochnoi vlasti na rossiiskom rynke electroenergii [Market Power Evidence from Electricity Market of Russian Federation], In EKO [ECO], 1, 102-126.

Bogers, M., Zobel, A-K., Afuah, A., Almirall, E., Brunswicker, S., Dahlander, L., Frederiksen, L., Gawer, A., Gruber, M., Haefliger, S., Hagedoorn, J., Hilgers, D., Laursen, K., Magnusson, M. G., Majchrzak, A., McCarthy, I. P., Moeslein, K. M., Nambisan, S., Piller, F. T., Radziwon, A., Rossi-Lamastra, C., Sims, J., Ter Wal, A. L. J. (2017). The open innovation research landscape: established perspectives and emerging themes across different levels of analysis, In Industry and Innovation, 24 (1), 8-40.

Cassiman, B., Veugelers, R. (2006). In Search of Complementarity in Innovation Strategy: Internal R\&D and External Knowledge Acquisition, In Management Science, 52 (1), 68-82.

Chiaroni, D., V. Chiesa, and F. Frattini. (2011). The Open Innovation Journey: How Firms Dynamically Implement the Emerging Innovation Management Paradigm, In Technovation, 31 (1), 34-43.

Dattee, B, Alexy, O, Autio, E. (2018). Maneuvering in Poor Visibility: How Firms Play the Ecosystem Game When Uncertainty Is High, In Academy of Management Journal, 61 (2), 466-498.

Davis, J. (2016). The Group Dynamics of Interorganizational Relationships: Collaborating with Multiple Partners in Innovation Ecosystems, In Administrative Science Quarterly, 61, 433-468.

Dedehayir, O., Ortt, J., Seppänen, M. (2017). Disruptive change and the reconfiguration of innovation ecosystems, In Journal of Technology Management \& Innovation, 12 (3), 9-20.

Demircioglu, M.A. (2016). Organizational Innovation, In Global Encyclopedia of Public Administration Public Policy and Governance. Springer, Cham, Switzerland, 6298 p.

Energy Strategy of Russia (2020). Available at: https://minenergo.gov.ru/node/1026 (accessed 14 January 2021).

Foss, K., Foss, N. J. (2005). Resources and Transaction Costs: How Property Rights Economics Furthers the Resource-based View, In Strategic Management Journal, 26 (6), 541-553.

Foss, N. J., Laursen, K., Pedersen, T. (2011). Linking Customer Interaction and Innovation: The Mediating Role of New Organizational Practices, In Organization Science, 22 (4), 980-999.

Foss, N. J., Lyngsie, J., Zahra, S. A. (2013). The Role of External Knowledge Sources and Organizational Design in the Process of Opportunity Exploitation, In Strategic Management Journal, 34 (12), 1453-1471.

Gioia, D., Corley, K., Hamilton, A. (2012). Seeking Qualitative Rigor in Inductive Research: Notes on the Gioia Methodology, In Organizational Research Methods, 16, 15-31.

Grigoriou, K, Rothaermel, F. T. (2014). Structural Microfoundations of Innovation: The Role of Relational Stars, In Journal of Management, 40 (2), 586-615.

Holgersson, M., Granstrand, O., Bogers, M. (2018). The evolution of intellectual property strategy in innovation ecosystems: Uncovering complementary and substitute appropriability regimes, In Long Range Planning, 51, 303-319. 
Jacobides, M., Cennamo, C., Gawer, A. (2018). Towards a theory of ecosystems, In Strategic Management Journal, 38, 2255-2276.

Khovalova, T.V. (2019). Innovatsii v elektroenergetike: vidy, klassificatsiia I effecty vnedreniia [Innovations in the electric power industry: types, classification and effects of implementation], In Strategicheskie resheniia \& Risk-menedzhment [Strategic Decisions \& Risk Management], 3, 274-283.

Kleiner, G. B., Rybachuk, M. A., Karpinskaya, V. A. (2020). Razvitie ekosistem v finansovom sektore Rossii [Development of ecosystems in the financial sector of Russia], In Upravlenets [The Manager], 4, $2-15$.

Kolloch, M., Dellermann, D. (2018). Digital innovation in the energy industry: The impact of controversies on the evolution of innovation ecosystems, In Technological Forecasting \& Social Change, 136, 254-264.

Langley, A. (1999). Strategies for theorizing from process data, In Academy of Management Review, 24, 691-710.

Luo, J. (2018). Architecture and evolvability of innovation ecosystems, In Technological Forecasting \& Social Change, 136, 132-144.

Markova, V. M., Churashev, V.N. (2020). Detsentralizatsiia energetiki: integratsiia I innovatsii [Energy Decentralization: Integration and Innovation], In EKO [ECO], 4, 8-27.

Mazzucchelli, A., Chierici, R., Abbate, T., Fontana, S. (2019). Exploring the microfoundations of innovation capabilities. Evidence from a cross-border R\&D partnership, In Technological Forecasting \& Social Change, 146, 242-252.

Nuruzzaman, N., Gaur, A. S., Sambharya, R. B. (2017). A microfoundations approach to studying innovation in multinational subsidiaries, In Global Strategy Journal, 9 (1), 92-116.

Ritala, P., Agouridas, V., Assimakopoulos, D., Gies, O. (2013). Value creation and capture mechanisms in innovation ecosystems: a comparative case study, In International Journal of Technology Management, $63(3 / 4), 244-267$.

Schueffel, P. (2015). Microfoundations of Open Innovation: The Antecedants of Openness and Innovation Performance, In Academy of Management Annual Meeting Proceedings, (1), 14019-14019.

Spradley, J. (1979). Interviewing an informant, In The Ethnographic interview. Holt, Rinehart and Winston. New York, $247 \mathrm{p}$.

Tavassoli, S., Karlsson, C. (2015). Firms' Innovation Strategies Analyzed and Explained. CESIS Electronic Working Paper Series Paper No. 396

Yin, R. (2009). Case Study Research Design and Methods (4th edition). Sage, Thousand Oaks, California, $219 \mathrm{p}$.

Zubakin, V. A. (2019). Gosudarstvennoe stimulirovanie transformatsii elektroenergetiki [State stimulation of transformation of power industry], In Strategicheskie resheniia \& Risk-menedzhment [Strategic Decisions \& Risk Management], 4, 320-329. 